R. F. Kornelisse

R. de Groot

H. J. Neijens

\section{Bacterial meningitis: mechanisms of disease and therapy}

Received: 13 May 1994

Accepted: 9 August 1994
R. F. Kornelisse (四) - R. de Groot

H. J. Neijens

Department of Paediatrics,

Division of Immunology

and Infectious Diseases,

Sophia Children's Hospital,

University Hospital Rotterdam,

Dr. Molewaterplein 60,

NL-3015 GJ Rotterdam,

The Netherlands

\begin{abstract}
Bacterial meningitis continues to be a serious infectious disease with a high morbidity and mortality in young children. Early recognition and initiation of adequate treatment are the major determinants for a good outcome. Recent advances in our understanding of the host inflammatory response by cytokines may result in the use of new therapeutic strategies. Such modulation of the inflammatory response may reduce the incidence of sequelae and death. The use of steroids as adjunctive therapy in children with bacterial meningitis probably has beneficial effects although the available data are still controversial. Additionally, studies in experimental meningitis models indicate that non-steroidal anti-inflammatory drugs and monoclonal antibodies against bacterial products, cytokines and $\mathrm{CD} 18$ on leucocytes reduce the extent of the
\end{abstract}

meningeal inflammation. Human studies to evaluate the efficacy of these immune modulators are expected to start soon. However, prevention of bacterial meningitis by conjugate vaccines against Streptococcus pneumoniae and Neisseria meningitidis will be the most promising development in the next decade.

Key words Bacterial meningitis Cytokines - Anti-inflammatory therapy

Abbreviations $A D H$ antidiuretic hormone $\cdot B B B$ blood brain barrier Hib Haemophilus influenzae type $\mathrm{b}$ $I F N$ interferon $\cdot I L$ interleukin $\cdot L P S$ lipopolysaccharide $P A F$ platelet activating factor $P G E_{2}$ prostaglandin $\mathrm{E}_{2} \cdot P M N$ polymorphonuclear leucocyte $\cdot$ SIADH syndrome of inappropriate secretion of antidiuretic hormone $\cdot T N F$ tumour necrosis factor

\section{Introduction}

Despite continuing improvements in therapy bacterial meningitis is still associated with fatality rates of $3 \%-6 \%$ and the development of severe sequelae in approximately $16 \%$ of cases $[6,33,86,101,115,116]$. Prevention of meningitis by the use of novel conjugate vaccines against Streptococcus pneumoniae and Neisseria meningitidis will be a point of major interest in the next decade. Recent research has contributed to our understanding of the pathophysiology of bacterial meningitis. This has resulted in new therapeutic approaches. The use of anti-inflamma- tory drugs in combination with antibiotics in bacterial meningitis has become a topic of major interest. This review will focus on the nature of the inflammatory response to infection in the CSF and the pathophysiological alterations induced by bacterial meningitis. Finally, recent advances in treatment will be discussed.

\section{Epidemiology}

Bacterial meningitis is mainly a disease of young children. During the neonatal period Gram-negative enteric bacilli (Escherichia coli, Klebsiella species), group B 
Fig. 1 Schematic view of the biochemical changes in the CSF profile and detection of elevated cytokine levels during bacterial meningitis. The normal ranges $(\mathrm{N})$ for white blood cells (WBC), protein, glucose and lactate in the CSF are indicated by vertical bars. $\mathrm{Rx}$ marks the timepoint of initiation of antibiotic therapy

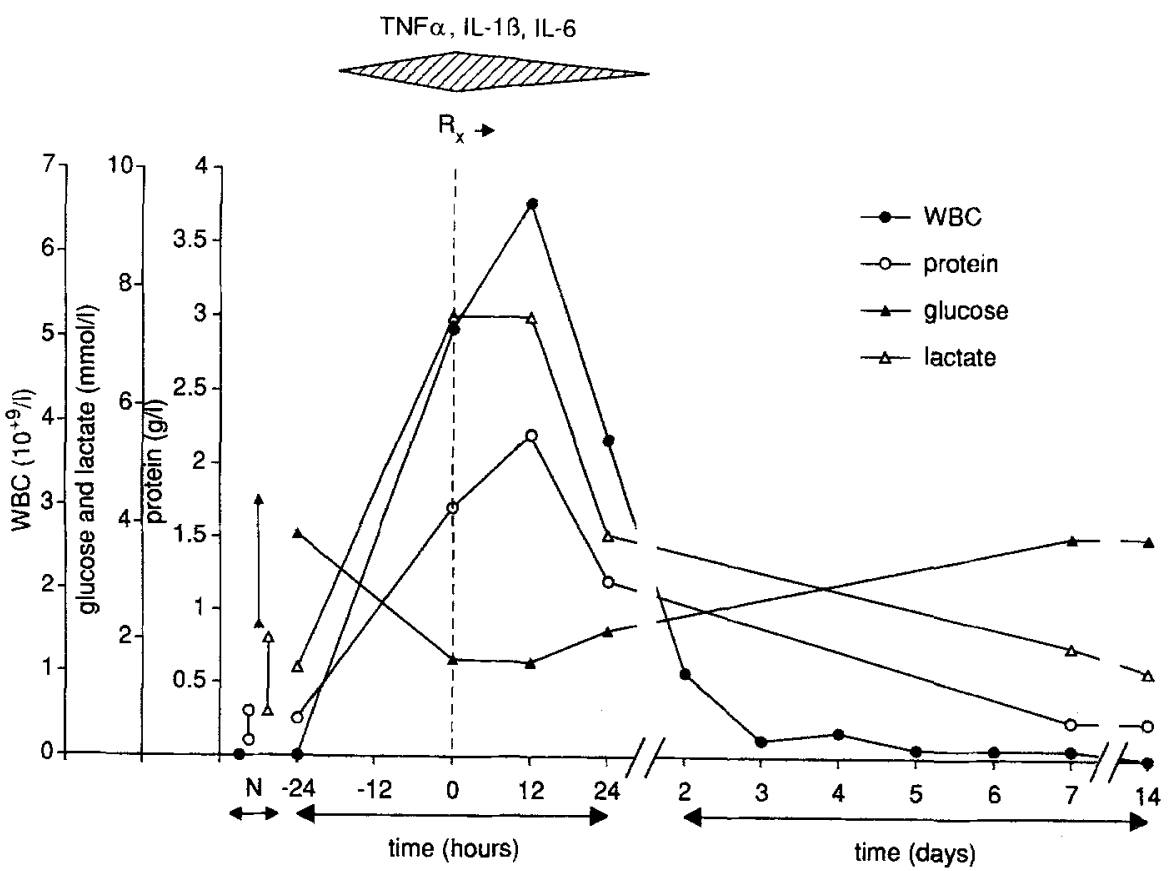

streptococci and Listeria monocytogenes are the most common pathogens. These organisms are mainly acquired at delivery. The three major causative organisms in infants above 3 months of age are $N$. meningitidis, Haemophilus influenzae and $S$. pneumoniae. They account for more than $90 \%$ of bacterial meningitis in children between 3 months and 10 years. The incidence and relative frequencies of these bacteria differ markedly depending on genetic factors, the geographic area and the recent introduction of the efficacious conjugate $H$. influenzae type b vaccine in many countries.

Epidemiological studies have identified several risk factors for bacterial meningitis. Age is the most important risk factor. Boys are affected more frequently than girls. Several studies have reported the presence of racial differences in the incidence of bacterial meningitis. Black and Hispanic populations are at 2-4 times greater risk than Caucasians $[26,31,35,130]$. Socioeconomic rather than racially determined factors are responsible for the increased risk [31]. The native North American population also has a high incidence of bacterial meningitis. For example, rates of over $200 / 100000$ per year in the overall population have been described among Canadian Inuits [132]. Another host factor which increases the risk of pneumococcal sepsis and meningitis is splenectomy. $\mathrm{Pa}-$ tients with deficiencies in the terminal components of complement (C5-9) also have a high risk of meningococcal meningitis. Children in day care centres have an increased risk of acquiring invasive bacterial disease in comparison with children in home care.

\section{Diagnosis of bacterial meningitis}

Nonspecific clinical findings predominate in the newborn and in young infants. These include abnormal temperature, somnolence, irritability, and poor feeding. The presence of a bulging fontanelle is a relatively characteristic sign in this age group but not present early in the disease. More characteristic findings are often seen in children and adults and include alteration of the mental status, nuchal rigidity, and the signs of Kernig and Brudzinski. A lumbar puncture has to be performed if the slightest evidence suggests the presence of bacterial meningitis. Rapid diagnosis and initiation of therapy are the major prognostic factors determining a favourable outcome. Initial management decisions are based largely on the Gram stain and CSF characteristics (leucocytes, glucose, lactate and protein). The CSF parameters reflect the metabolic and structural alterations, such as increased blood brain barrier (BBB) permeability, which characterize the inflammatory response (Fig. 1).

\section{Leucocytes}

A characteristic feature of meningitis is CSF leucocytosis. Before leucocytes reach the CSF a co-ordinated action takes place of adherence to vascular endothelium, diapedesis out of the bloodstream and subsequent migration across the endothelial monolayer into the CSF compartment. This process is mediated by adhesion-promoting receptors and ligands located on leucocytes and endothelium which are activated by exposure to cytokines (interleukin (IL)-1 $\beta$, tumour necrosis factor (TNF) $\alpha$ and inter- 
feron (IFN) $\gamma$ ) and lipopolysaccharide (LPS) $[62,68,84$, $85,93]$. Bacterial replication or lysis in the CSF compartment induces endothelial cells to produce $\mathrm{IL}-8$. IL- 8 is a potent chemoattractant [5]. The initial reversible adherence of leucocytes to endothelial cells is mediated by three lectin-like carbohydrate-binding molecules called selectins (granule membrane protein-140, endothelial cell adhesion molecule-1, leucocyte adhesion molecule-1). Each selectin recognises specific carbohydrate sequences on either leucocytes (granule membrane protein-140, endothelial cell adhesion molecule-1) or endothelial cells (leucocyte adhesion molecule-1). Strong adhesion is mediated by leucocyte integrins that bind to counter receptors on endothelium. The integrin family of adhesion receptors (CD11/CD18) consist of heterodimeric glycoproteins with an $\alpha$ and $\beta$ subunit. They can be classified on basis of their $\beta$ subunit [46]. The early selectin-adhesion decreases with continued cytokine stimulation by cleavage of the selectin of the cell surface or inhibition of its binding. At the same time $\beta_{2}$ integrin-mediated adherence of the neutrophils to intercellular adhesion molecule-1 (ligand) on endothelial cells is induced. Subsequently leucocytes traverse the cerebral capillary endothelium by diapedesis [103].

\section{Glucose and lactate}

The changes in glucose and lactate levels are not only induced by living bacteria and leucocytes. The anaerobic brain metabolism in bacterial meningitis contributes to the development of increased CSF lactate concentration and hypoglycorrhachia [123]. It seems likely that local changes in the brain as a result of ischaemia or mediated by humoral factors, induce an increased production of lactate. Another explanation for the development of hypoglycorrhachia was demonstrated in experimental canine meningitis. In these animals low CSF glucose reflected the inhibition of carrier-mediated transport across the BBB $[21,88]$. The increased use of glucose by the brain and the abnormal glucose transport across the BBB may further contribute to hypoglycorrhachia [43].

\section{Protein}

The elevated concentration of protein in CSF during bacterial meningitis is caused by an increased permeability of the $\mathrm{BBB}$. A uniform response consisting of an early and sustained increase in formation of pinocytotic vesicles and a progressive increase in the separation of tight junctions between endothelial cells is observed during the course of experimental meningitis [99]. The cytokine-endothelium-leucocyte interaction is probably responsible for the disruption of the barrier by opening intercellular junctions and permitting the passage of serum proteins into the subarachnoidal space.

\section{Pathogenesis of infection}

The three most common micro-organisms in bacterial meningitis have several properties that promote adherence, colonization and invasion of the mucous membranes of the nasopharynx. Mucosal attachment is mediated by microbial virulence factors such as pili and nonpilar adhesins. Several host defence mechanisms must be evaded before attachment may occur. The bacteria have to inactivate secretory IgA and escape from the ciliary clearance mechanisms of the nasopharyngeal mucosa. The three major pathogens all secrete a protease capable of cleaving human immunoglobulin A1. Importantly, IgA1 is the dominant immunoglobulin class in the nasopharyngeal mucosa which is the site of adherence and invasion by these bacteria $[24,83]$.

Invasion across the nasopharyngeal mucosa takes place by an endocytotic process ( $N$. meningitidis) or through the intercellular route by separations in the apical tight junctions of columnar epithelial cells ( $H$. influenzae) $[106,107]$. Once the mucosal barrier is crossed, bacteria must overcome additional host defences to survive in the bloodstream and to invade the meninges. The most important virulence factor in this respect is encapsulation. The polysaccharide capsule inhibits neutrophil phagocytosis and prevents classical complement pathway bactericidal activity thus enhancing intravascular bacterial replication and survival.

\section{Pathophysiology of the inflammatory response}

Since CSF defences against infection are very limited bacteria can proliferate rapidly. Host defence (humoral factors and phagocytes) must be recruited from serum, a process that develops parallel to blood brain barrier disruption and alteration of the cerebral metabolism. These abnormalities all arise as part of an inflammatory response mediated by cytokines.

\section{Cell-wall components}

Experimental evidence has accumulated that cell-wall components are responsible for triggering the inflammatory response in the subarachnoid space. These are mainly peptidoglycan-teichoic acid in Gram-positive micro-organisms and LPS molecules (endotoxins) in Gram-negative bacteria. Both are potent inducers of inflammation. Intracisternal inoculation of any of these components into the CSF compartment of animals induces meningeal inflammation $[110,117,118,131]$. Observations in animals with experimental pneumococcal as well as $H$. influenzae meningitis indicate that initiation of antibiotic therapy results in a more pronounced increase in inflammatory in- 
dices and cytokine levels in the CSF $[71,112,119]$. Additional evidence indicates that LPS does not act alone during Gram-negative bacillary meningitis [11]. These bacteria also contain similar amounts of peptidoglycan [48]. LPS is not present in the CSF in sufficiently high concentrations to directly injure the cerebrovascular endothelium. In contrast, clinically relevant concentrations of LPS (1-10 ng/ml) are able to induce CSF leucocytosis and are potent at priming leucocytes for the production of inflammatory mediators. Peptidoglycan is only a weak inducer of inflammatory mediators. However, peptidoglycan can cause cellular separation of endothelia at concentrations 100 -fold less than required for LPS and may be responsible for the induction of $\mathrm{BBB}$ permeability in Gram-negative meningitis [74].

Two studies in infants with Gram-negative meningitis have demonstrated increased endotoxin concentrations in $\mathrm{CSF}$ and ventricular fluid when intrathecal or intraventricular antibiotic therapy was given in addition to parenteral antibiotics. This increased endotoxin concentrations have been associated with an augmented meningeal inflammation and with a rise in adverse outcome in infants with coliform meningitis treated with intraventricular gentamicin $[3,65,66,70]$.

\section{Cytokines}

The host responds with the release of cytokines upon recognition of the presence of bacterial products in the subarachnoidal space. TNF $\alpha$ and $I L-1 \beta$ appear to play a pivotal role in triggering the cascade of meningeal inflammation [91]. Il-6, another cytokine found in CSF from patients with bacterial meningitis, has also been implicated in the pathogenesis of this infection. Although production of these inflammatory cytokines has been linked to the development of CNS injury, the precise mechanism has not been elucidated. It has been suggested that cytokines are produced by glial cells and brain capillary endothelial cells [67]. Experimental studies have indicated that intracisternal inoculation of endotoxin is followed by detection of TNF $\alpha$ and IL-1 $\beta$ activity. Subsequently, leucocytosis and changes in protein, glucose and lactate concentrations are observed within hours. Combined injection of TNF $\alpha$ and IL- $1 \beta$ into the CSF has a synergistic effect [119]. Administration of dexamethasone or polymyxin $b$ before or together with $H$. influenzae type b (Hib) lipooligosaccharide, inhibits CSF TNFO and decreases the meningeal inflammatory response [51, 71, 72, 109]. TNF $\alpha$ and IL- $1 \beta$ can also be detected in initial CSF samples of children with bacterial meningitis [126]. The presence of $I L-1 \beta$ is associated with CSF inflammatory abnormalities, TNF $\alpha$ concentration and an adverse outcome [69]. Some reports describe an association between indices of inflammation or the clinical course and TNF $\alpha$, IL-1 $\beta$ and IL-6 levels. Infants with culture-proven viral meningitis or with non-infected CSF have low or nondetectable IL-1 $\beta$ and TNF $\alpha$ levels $[18,39,59,61,77,90]$.

Arachidonic acid metabolites

Arachidonic acid metabolites play an important role as mediators and/or modulators of inflammation. These products may be involved in many of the pathological processes in meningitis. They are released after stimulation with bacterial and immunological antigens by a variety of cells, including neutrophils, platelets, and vascular endothelial cells. TNF $\alpha$ and IL-1 $\beta$ induce phospholipase $\mathrm{A}_{2}$ activity thereby triggering the production of these proinflammatory substances [64].

Previous studies have demonstrated a significant increase in prostaglandin $\mathrm{E}_{2}\left(\mathrm{PGE}_{2}\right)$ (cyclo-ogygenase products) but not leukotriene $\mathrm{B}_{4}$ (lipo-oxgygenase product) concentration in CSF during pneumococcal meningitis in rabbits [49]. Intracisternally administered $\mathrm{PGE}_{2}$ did not induce detectable CSF leucocytosis, but caused a dose-related increase in protein content [50]. $\mathrm{PGE}_{2}$ and $\mathrm{PGI}_{2}$ are elevated in the CSF of infants and children with bacterial meningitis. The concentration of $\mathrm{PGE}_{2}$ correlates significantly with protein, TNF $\alpha$, and IL-1 $\beta$ concentrations in the initial CSF sample [73].

PAF

CSF platelet activating factor (PAF) concentrations are significantly higher in children with $\mathrm{H}$. influenzae meningitis than in afebrile and febrile control subjects without meningitis. The concentrations correlate strongly with concomitant bacterial counts and with both LPS and TNF $\alpha$ concentrations in admission CSF samples. LPS and a variety of cytokines, such as TNF $\alpha$ and IL-1 $\beta$, are potent inducers of PAF by polymorphonuclear leucocytes $(\mathrm{PMN})$, macrophages/monocytes, endothelial cells and neuronal cells $[8,82,125]$. PAF recruits and activates PMNs and monocytes at the site of inflammation and induces the release of other inflammatory mediators. PAF in high concentrations is toxic to neuronal cells. PAF acts synergistically with LPS and TNF $\alpha$ in the development of microvascular tissue damage $[4,12]$.

\section{Leucocytes}

Several hours after meningeal infection an intense influx of leucocytes occurs. Cytokines stimulate the function of neutrophils and provoke degranulation superoxide production and increased adherence to the endothelium. It has been demonstrated that products of leucocytes, such as polyunsaturated fatty acids and oxygen-free radicals can induce brain oedema, increased lactate production, 
and energy depletion in cortical brain slices of rats [16, 28]. However, not all studies demonstrate adverse effects of leucocytes. When the effects of experimental pneumococcal meningitis were compared between normal and neutropenic rabbits similar changes of brain water content (brain oedema), intracranial pressure, and CSF concentration of lactate and protein were observed [113].

\section{Therapy}

\section{Antimicrobial therapy}

The combination of ampicillin and chloramphenicol has been known for many years as an effective empirical therapy of bacterial meningitis. Ampicillin resistant $\beta$-lactamase producing $H$. influenzae has become a major problem in many European countries and the United States of America. A recent collaborative European study shows a mean rate of resistance of $10 \%$ for all participating countries [63]. In addition, sporadic cases of chloramphenicolresistant $H$. influenzae have been documented. Combined resistance to chloramphenicol and beta-lactams is increasing $[13,14,36,42,102,124] . N$. meningitidis resistant to $\beta$-lactam antibiotics is also increasingly encountered. Spain has been a major source for penicillin-resistant $N$. meningitidis [96]. Infections caused by resistant pathogens lead to higher rates of morbidity and mortality than infections caused by susceptible pathogens.

A consensus among experts about the choice of initial empiric therapy of childhood meningitis is still lacking. Third generation cephalosporins have become important antibiotics for the treatment of presumed bacterial meningitis in infants and children [19, 56, 75, 104]. Among these cephalosporins, cefotaxime, ceftriaxone, and ceftazidime have been studied extensively $[32,44,92]$. All three agents are extremely active against $H$. influenzae (including $\beta$-lactamase producing strains), $N$. meningitidis and $S$. pneumoniae. However, cephalosporins are inactive against Listeria monocytogenes, Streptococcus faecalis and methicillin-resistant staphylococci. Empiric therapy of bacterial meningitis in children up to 3 months of age should include ampicillin for activity against $L$. monocy. togenes and enterococci. Once the aetiological agent has been identified and its susceptibility determined, therapy can be altered to a single drug or a combination of drugs active in vitro. The duration of therapy is dependent on the clinical response of the patients. Seven days is generally considered adequate for meningococcal infections and 10 days for $H$. influenzae and pneumococcal meningitis [89]. Despite the availability of active antibiotics against the common meningeal pathogens the outcome of meningitis has not changed over the last decades. Therefore investigators have been focusing on novel approaches to diminish neurological sequelae of meningitis.

\section{Fluid restriction}

It is generally recommended that children with bacterial meningitis receive less than maintenance fluid to treat or prevent the syndrome of inappropriate secretion of antidiuretic hormone (SIADH) [25, 52]. However, a recent study in infants with bacterial meningitis shows that elevated levels of antidiuretic hormone $(\mathrm{ADH})$ may also be explained as an appropriate response to intravascular volume depletion rather than as the result of hypothalamicpituitary axis dysfunction [87]. The loss of cerebrovascular autoregulation in bacterial meningitis may be compensated by secretion of $\mathrm{ADH}$ to maintain adequate cerebral blood flow. The cerebral blood flow during bacterial meningitis depends on the cerebral perfusion pressure which is the difference between the mean arterial blood pressure and the intracranial pressure. Two studies in rabbits with experimental meningitis compared fluid restriction with a normal fluid regimen. Fluid restriction resulted in reduced mean arterial blood pressure, significantly decreased cerebral blood flow and increased anaerobic glycolysis of the brain. The fluid regimen, however, did not have a major effect on the degree of brain oedema [114, 123]. Since cerebral blood flow is often reduced in bacterial meningitis, fluid restriction may even worsen the neurological outcome. Clinical trials to evaluate the effect of fluid regimen on outcome have not been performed. Current recommendation in children with bacterial meningitis may have to be revised in view of these new experimental data. Fluid restriction should possibly only be limited to those patients with meningitis who fulfil the diagnostic criteria for SIADH.

\section{Adjunctive therapy}

The improvements in our understanding of the pathophysiology of bacterial meningitis may lead to the development of novel therapeutic approaches. Modulation of the inflammatory cascade may reduce the incidence of sequelae and death in patients with bacterial meningitis. Interventions will be directed against harmful bacterial products (e.g. monoclonal antibodies, polymyxin B), cytokines (e.g. monoclonal antibodies, steroids), leucocytes (e.g. monoclonal antibodies, pentoxiphylline, radical scavengers) or some consequences of the disease, e.g. brain oedema, increased intracranial pressure or alterations of the cerebral blood flow (Table 1).

\section{Corticosteroids}

In vitro studies indicate that pretreatment of cultured cells with dexamethasone suppresses the synthesis and release of cytokines induced by bacterial products $[9,54,58]$. The inflammatory response in the CSF of rabbits after in- 
Table 1 Adjunctive anti-inflammatory agents in the treatment of bacterial meningitis

- Corticosteriods

- Monoclonal antibodies

- Anti-endotoxin

- Anti-IL-1 $\beta$; anti-TNF $\alpha$

- Anti-CD18

- Cyclo-oxygenase inhibitors

- Pentoxifylline

- Radical scavengers

- Superoxide dismutase

- Catalase

tracisternal inoculation of bacterial products such as endotoxin or live $H$. influenzae may be blocked by dexamethasone. However, this is only effective when dexamethasone is initiated before or at the same time as the antibiotic $[51,71,72]$. TNF $\alpha$ and $I L-1 \beta$ levels in the CSF are reduced concomitantly with concentrations of $\mathrm{PGE}_{2}$ [73]. Dexamethasone also decreases brain water content, intracranial pressure, and CSF lactate in animals with $S$. pneumoniae or $H$. influenzae meningitis $[100,109,111]$.

Clinical studies to evaluate the efficacy of dexamethasone in bacterial meningitis have yielded controversial results (Table 2). Lebel et al. [57] demonstrated that con- ventional antibiotic therapy (cefuroxim or ceftriaxone) plus dexamethasone resulted in improved outcome in the treatment group in comparison with a placebo-treated group. Children treated with dexamethasone had a significantly lower incidence of sensorineural deafness $(15 \%$ vs $3.3 \%$ ) and of other neurological sequelae 12 months later [57]. The study of Odio et al., in which dexamethasone administration was started before the initiation of cefotaxime therapy failed to find a significant reduction in hearing impairment in the steroid treated group. However, an overall reduction in the incidence of neurological complications (including hearing loss) was seen in the treatment group in comparison with a placebo group (14\% vs $38 \%$ ) [76]. The majority of cases of meningitis in these two studies were due to $H$. influenzae while $N$. meningitidis and $S$. pneumoniae will become more important in the coming years due to the introduction of Haemophilus conjugate vaccines. In a study from Egypt mortality was reduced in patients (children and adults) with pneumococcal meningitis by using dexamethasone. This corticosteroid also protected against hearing loss in this group of patients [38]. These three studies showed a significant reduction in neurological sequelae with dexamethasone, but benefits were statistically significant only when the sequelae were unusually common as result of suboptimal therapy (cefuroxim), supportive, and diagnostic management (in developing countries). The results of these studies could not be confirmed in more recent trials, which de-
Table 2 Overview of sequelae in recent placebo/dexamethasone therapy studies in children treated for bacterial meningitis ( $S E Q$ sequelae, $N A$ not available, $N S$ not significant)

\begin{tabular}{|c|c|c|c|c|c|}
\hline \multirow[t]{2}{*}{ Study } & \multirow[t]{2}{*}{$\begin{array}{l}\text { Antibiotic } \\
\text { therapy }\end{array}$} & \multicolumn{3}{|c|}{$\begin{array}{l}\text { No }(\%) \text { of children with audiological (A), } \\
\text { neurological }(\mathrm{N}) \text { or combined (C) sequelae }\end{array}$} & \multirow[t]{2}{*}{$P$} \\
\hline & & SEQ & Placebo & Dexamethasone & \\
\hline Lebel et al. [57] & Cefuroxim & $\begin{array}{l}\mathrm{A} \\
\mathrm{N} \\
\mathrm{C}\end{array}$ & $\begin{array}{rrr}16 / 38 & (42) \\
3 / & 34 & (9) \\
\mathrm{NA} & & \end{array}$ & $\begin{array}{rrr}9 / 43 & (21) \\
1 / 38 & (3) \\
\mathrm{NA} & & \end{array}$ & $\begin{array}{l}<0.05 \\
\text { NS } \\
\text { NA }\end{array}$ \\
\hline Lebel et al. [57] & Ceftriaxone & $\begin{array}{l}\mathrm{A} \\
\mathrm{N} \\
\mathrm{C}\end{array}$ & $\begin{array}{rll}14 / 46 & (30) \\
6 / 41 & (15) \\
\text { NA } & & \end{array}$ & $\begin{array}{rrr}7 / 49 & (14) \\
2 / 43 & (5) \\
\text { NA } & & \end{array}$ & $\begin{array}{l}\text { NS } \\
\text { NS } \\
\text { NA }\end{array}$ \\
\hline Odio et al. [76] & Cefotaxime & $\begin{array}{l}\mathrm{A} \\
\mathrm{N} \\
\mathrm{C}\end{array}$ & 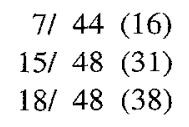 & $\begin{array}{lll}5 / & 50 & (6) \\
5 / & 51 & (10) \\
7 / & 51 & (14)\end{array}$ & $\begin{array}{l}\text { NS } \\
0.008 \\
0.007\end{array}$ \\
\hline King et al. [55] & Not uniform & $\begin{array}{l}\mathrm{A} \\
\mathrm{N} \\
\mathrm{C}\end{array}$ & $\begin{array}{rll}4 / & 51 & (9) \\
3 / & 51 & (7) \\
\text { NA } & & \end{array}$ & $\begin{array}{rrr}5 / 48 & (11) \\
3 / 48 & (6) \\
\mathrm{NA} & & \end{array}$ & $\begin{array}{l}\text { NS } \\
\text { NS } \\
\text { NA }\end{array}$ \\
\hline Wald et al. [127] & Ceftriaxone & $\begin{array}{l}\mathrm{A} \\
\mathrm{N} \\
\mathrm{C}\end{array}$ & $\begin{array}{l}\text { NA } \\
\text { NA } \\
10 / 74(14)\end{array}$ & $\begin{array}{l}\text { NA } \\
\text { NA } \\
6 / 68\end{array}$ & $\begin{array}{l}\text { NA } \\
\text { NA } \\
\text { NS }\end{array}$ \\
\hline Schaad et al. [98] & Ceftriaxone & $\begin{array}{l}\mathrm{A} \\
\mathrm{N} \\
\mathrm{C}\end{array}$ & $\begin{array}{lrr}8 / & 55 & (15) \\
5 / & 55 & (9) \\
9 / & 55 & (16)\end{array}$ & $\begin{array}{lll}3 / & 60 & (5) \\
3 / 60 & (5) \\
3 / 60 & 60\end{array}$ & $\begin{array}{l}\text { NS } \\
\text { NS } \\
\text { NS }\end{array}$ \\
\hline $\begin{array}{r}\text { Schaad et al. [98] } \\
\text { (meta-analysis) }\end{array}$ & Ceftriaxone & $\mathrm{C}$ & $28 / 175(16)$ & $12 / 177$ & 0.007 \\
\hline
\end{tabular}


tected no significant difference between steroid-treated patients and control subjects $[55,98,127]$. However, a meta-analysis of sequelae in ceftriaxone-treated bacterial meningitis in children indicated that dexamethasone as adjuvans therapy is superior to placebo [98]. The American Academy of Pediatrics advises to use dexamethasone in patients with proven or strongly suspected bacterial meningitis. However, the Canadian Pediatric Society has not yet decided to recommend routine use of dexamethasone therapy $[2,47]$.

Furthermore, the use of corticosteroids is associated with potential side-effects supporting the need for more information to assess the risks or benefits [45]. In the report by Lebel et al. [57], $2 \%$ of the patients had gastro-intestinal bleeding. None of the patients receiving placebo had this complication. At present, the frequency and severity of this complication of dexamethasone are unknown. Other studies indicate that glucocorticoids potentiate ischaemic injury to neurons. Since decreased cerebral blood flow appears to be one of the pathophysiological features of bacterial meningitis, it is important to know whether dexamethasone has beneficial effects on hearing but worsens cerebral cortical function [97]. These important questions concerning the place of corticosteroids should be addressed further in carefully conducted clinical trials in homogeneous populations.

\section{Monoclonal antibodies against endotoxin}

Inhibition of the effects of endotoxin may have beneficial effects on Gram-negative bacterial meningitis since the toxic moiety of endotoxins, lipid $\mathrm{A}$, can be neutralized by polymyxin B or by a monoclonal antibody to lipid A [7, $128,133,134]$. Indeed, cures of bacterial meningitis were achieved in the pre-antibiotic era by direct installation of immune serum supplemented with complement $[1,27,29$, 30]. Direct CSF inoculation was needed for this therapy. Experimental studies in rats demonstrate that intravenous administration of an IgG monoclonal antibody results in low CSF levels $(\leq 5.5 \%)$ [37]. Intracisternal inoculation of an IgM monoclonal antibody or polymyxin b directed against the lipid A moiety of $E$. coli LPS reduced the cefotaxim-induced increase in CSF LPS concentration and brain water content. The monoclonal antibody was clearly more effective in reducing brain water content although no differences were observed in the capacity to neutralize endotoxin [112].

\section{Monoclonal antibodies against cytokines}

Intracisternal administration of TNF $\alpha$ and IL-1 $\beta$ in rabbits induces a brisk inflammatory response which may be blocked by antibodies against the cytokines. Moreover, simultaneous intracisternal administration of anti-TNFo polyclonal antibody with Hib lipooligosaccharides neutral- izes CSF TNF $\alpha$ activity and is associated with substantial attenuation of the meningeal inflammatory changes [72].

\section{Monoclonal antibodies against CD18}

Agents that attenuate the augmented granulocyte-endothelial interaction followed by leucocyte influx into CSF could be beneficial in preventing brain damage. Monoclonal antibodies against the CD18 family of adhesion-promoting receptors on leucocytes have been studied. Animals receiving intravenous mAb IB4 (anti-CD18) before intracisternal inoculation with living bacteria $(S$. pneumoniae, $H$. influenzae, $N$. meningitidis), endotoxin or cell-wall demonstrate a dramatic reduction in CSF leucocyte density and protein concentration. Cerebral oedema was absent in mAb-treated animals [95, 120].

\section{Inhibition of prostaglandins}

Non-steroidal anti-inflammatory agents inhibit the cyclooxygenase pathway and reduce meningeal inflammation in bacterial meningitis. Cyclo-oxygenase inhibitors (indomethacin, diclofenac, oxindanac) block the development of brain oedema and decrease the number of leucocytes in comparison with non-treated animals. In addition, the influx of protein in the CSF compartment is prevented by these inhibitors. Oxindanac has a stronger activity than other cyclo-oxygenase inhibitors (indomethacin, diclofenac). A study in rabbits with experimental meningitis demonstrated a dramatically decreased mortality by the use of a combination of ampicillin plus oxindanac in comparison with treatment with ampicillin alone or ampicillin plus dexamethasone or indomethacin. Trials of selected nonsteroidal anti-inflammatory agents hold much promise $[49,50,119,121,122]$.

\section{Pentoxifylline}

Recent studies suggest that pentoxifylline, a xanthine-derived phosphodiesterase inhibitor, can inhibit the inflammatory process. Pentoxifylline can reverse or counteract many of the effects of endotoxin and endotoxin-induced cytokines on leucocyte function [108]. Studies in rabbits with experimental meningitis indicate that continuous intravenous infusion of pentoxifylline compared with saline significantly reduces CSF concentrations of leucocytes, protein, and lactate [94]. Pentoxifylline also reduces the release of cytokines from primary murine microglial cell cultures. When added concomitantly with LPS, pentoxifylline blocked the release of TNF $\alpha$ and $\Pi L-1 \beta$ but not IL-6, while dexamethasone inhibited the release of TNF $\alpha$ and IL-6. Pentoxifylline, but not dexamethasone, inhibited TNF $\alpha$ release from microglia previously stimulated with LPS [17]. 


\section{Radical scavengers: superoxide dismutase and catalase}

Reactive oxygen species in experimental meningitis are capable of inducing vasodilation of cerebral arterioles, increased BBB permeability, increased lactate production and brain oedema. Pfister et al. studied the effects of two radical scavengers in experimental meningitis. Superoxide dismutase completely blocked the increase of regional blood flow, intracranial pressure, and brain water content during the early phase of experimental pneumococcal meningitis. Catalase, another radical scavenger, only partly attenuated the increase of regional cerebral blood flow, intracranial pressure and brain water content. These results suggest that the increase of regional cerebral blood flow, brain water content, and intracranial pressure is mainly caused by superoxide or its products $[80,81]$.

\section{Vaccination}

Recently, conjugate vaccines against Hib have been developed. These vaccines, but not the previous non-conjugated ones, are immunogenic and effective during the age of the highest incidence of meningitis caused by Hib. A very low rate of side-effects was noted $[20,22,23,40$, $41,53,78,129]$. Hence, Hib vaccination has been introduced in childhood vaccination programmes in an increasing number of countries. Subsequently a $90 \%$ reduction in $H$. influenzae meningitis has been observed [23, 79]. However, a substantial number of children have bacterial meningitis caused by $N$. meningitidis and $S$. pneumoniae. Meningococcal disease is caused by several serogroups $N$. meningitidis; serogroup B is the most common cause in Europe, North-America and several countries in Latin America. A meningococcal non-conjugate tetravalent $\mathrm{A}, \mathrm{C}, \mathrm{Y}$, and $\mathrm{W} 135$ polysaccharide vaccine is available and has been shown to be safe and immunogenic in adults, but not in young infants. The serogroup B polysaccharide, however, is poorly immunogenic in humans and has not been useful for development of a vaccine. Therefore, vaccines based on outer membrane proteins are currently being evaluated for their efficacy $[34,60]$. Recent field trials with such vaccines have demonstrated only partial protection against group B infection $[10,15]$. Several pneumococcal conjugate vaccines combining the most relevant serotypes coupled to different protein antigens are already available [105].

The final aim would be a combined conjugate vaccine, including adequate immunogenic structures of Hib, meningococci and pneumococci to provide a protective antibody response at an early age.

\section{Conclusions}

Brain damage in patients with bacterial meningitis results from the combined deleterious effects of the micro-organisms and its products and of the host inflammatory response. A number of pathophysiological alterations have been demonstrated in animal models. These include brain oedema, elevation of intracranial pressure, changes in CSF outflow resistance, morphological changes of the $\mathrm{BBB}$, and changes in cerebral blood flow. In addition, mediators of pathophysiological changes have been identified, including cytokines, cyclo-oxygenase metabolites, and PAF. Several adjunctive therapeutic interventions have been developed to modulate the damaging host response to invading micro-organisms. The new treatment strategies are directed against bacterial products, cytokines and white blood cells. Most of these adjunctive therapies have only shown advantageous effects when administered before or simultaneously with the induction of experimental meningitis. However, pentoxifylline has been shown to attenuate the inflammatory process by reducing the release of cytokines in a model previously exposed to endotoxin. The use of corticosteroids as adjunctive treatment in human studies shows the presence of a possible beneficial effect. Nevertheless, routine use of steroids in children with bacterial meningitis is still a subject of intense debate because recent studies did not demonstrate a significant difference in the percentage of neurological or audiological sequelae. Although improvement of treatment strategies has given encouraging results, prevention of bacterial meningitis by development and introduction of a combined conjugate vaccine against the three common causative pathogens will be the major challenge of the next decade.

\section{References}

1. Alexander HE (1943) Treatment of Haemophilus influenzae infections and of meningococcic and pneumococcic meningitis. Am J Dis Child 66: 172-187

2. American Academy of Pediatrics (1991) Report of the Committee on infectious diseases, 22nd edn. Am Acad Pediatr, Elk Groove Village, pp $324,375,566-577$
3. Arditi M, Ables L, Yogev R (1989) Cerebrospinal fluid endotoxin levels in children with $H$. influenzae meningitis before and after administration of intravenous ceftriaxone. J Infect Dis 160: 1005-1011
4. Arditi M, Manogue KR, Caplan M, Yogev R (1990) Cerebrospinal fluid cachectin/tumor necrosis factor- $\alpha$ and platelet-activating factor concentrations and severity of bacterial meningitis in children. J Infect Dis 162: 139-147 
5. Baggiolini M, Walz A, Kunkel SL (1989) Neutrophil-activating peptide$1 /$ interleukin 8 , a novel cytokine that activates neutrophils. J Clin Invest 84: 1045-1049

6. Baraff LJ, Lee SI, Schriger DL (1993) Outcomes of bacterial meningitis in children: a meta-analysis. Pediatr Infect Dis J 12: 389-394

7. Baumgartner J-D, Allen McCutchan J, Melle G van, Vogt M, Luethy R, Glauser MP, Ziegler EJ, Klauber MR, Muehlen E, Chiolero R, Geroulanos S (1985) Prevention of gram-negative shock and death in surgical patients by antibody to endotoxin core glycolipid. Lancet : 59-63

8. Betz SJ, Henson PM (1980) Production and release of platelet-activating factor (PAF); dissociation from degranulation and superoxide production in the human neutrophil. J Immunol 125: 2756-2763

9. Beutler B, Krochin N, Milsark IW, Luedke C, Cerami A (1986) Control of cachectin (tumor necrosis factor) synthesis: mechanism of endotoxin resistance. Science 232: 977-980

10. Bjune G, Hoiby EA, Gronnesby JK, Arnesen O, Fredriksen JH, Halstensen A, Holten E, Lindbak A-K, Nokleby H, Rosenqvist E, Solberg LK, Closs O, Eng J, Froholm LO, Lystad A, Bakketeig LS, Hareide B (1991) Effect of outer membrane vesicle vaccine against group B meningococcal disease in Norway. Lancet : 1093-1096

11. Burroughs M, Cabellos C, Prasad S, Tuomanen E (1992) Bacterial components and the pathophysiology of injury to the blood-brain barrier: does cell wall add to the effects of endotoxin in gram-negative meningitis? J Infect Dis 165: S82-85

12. Cabellos C, Macintyre DE, Forrest M, Burroughs M, Prasad S, Tuomanen E (1992) Differing roles for platelet-activating factor during inflammation of the lung and subarachnoid space. J Clin Invest 90: 612-618

13. Campos J, García-Tornel S, Sanfeliu I (1984) Susceptibility studies of multiply resistant Haemophilus influenzae isolated from pediatric patients and contacts. Antimicrob Agents Chemother 25: 706-709

14. Campos J, García-Tornel S (1987) Comparative susceptibilities of ampicillin and chloramphenicol resistant Haemophilus influenzae to fifteen antibiotics. J Antimicrob Chemother 19 : 297-301
15. Cassio de Moraes J, Perkins BA, Camargo MCC, Rossetto Hidalgo NT, Aparecida Barbosa H, Tavares Sacchi C, Land Gral IM, Gattas VL, G Vasconcelos $\mathrm{H}$ de, Plikaytis $\mathrm{BD}$, Wenger JD, Broome CV (1992) Protective efficacy of a serogroup $B$ meningococcal vaccine in Sao Paulo, Brazil. Lancet 340: 1074-1078

16. Chan PH, Fishman RA (1979) Brain edema: induction in cortical slices by polyunsaturated fatty acids. Science 201: $358-360$

17. Chao CC, Hu S, Close K, Choi CS, Molitor TW, Novick WJ, Peterson PK (1992) Cytokine release from microglia: differential inhibition by pentoxifylline and dexamethasone. J Infect Dis 166: 847-853

18. Chavanet P, Bonnotte B, Guiguet $M$, Zeller V, Solary E, Maurice L, Casasnovas O, Caillot D, Waldner A, Kisterman JP, Portier H (1992) High concentrations of intrathecal interleukin- 6 in human bacterial and nonbacterial meningitis. J Infect Dis 166: 428-431

19. Cherubin CE, Eng RHK, Norrby R, Modai J, Humbert G, Overturf $G$ (1989) Penetration of newer cephalosporins into cerespinal fluid. Rev Infect Dis 11: 526-548

20. Clemens JD, Ferreccio C, Levine MM, Horwitz I, Rao MR, Eng M, Edwards KM, Fritzell B (1992) Impact of Haemophilus influenzae type b polysaccaride-tetanus protein conjugate vaccine on responses to concurrently administered diphtheria-tetanuspertussis vaccine. JAMA 267: 673-678

21. Cooper A, Beaty H, Oppenheimer S, Goodner R, Petersdorf R (1968) Studies on the pathogenesis of meningitis. Glucose transport and spinal fluid production in experimental pneumococcal meningitis. J Lab Clin Med 71: $473-483$

22. Eskola J, Peltola H, Takala AK, Käyhty $H$, Hakulinen M, Karanko V, Kela E, Rekola P, Rönnberg PR, Samuelson JS, Gordon LK, Mäkelä PH (1987) Efficacy of Haemophilus in fluenzae type b polysaccharide-diphtheria toxoid conjugate vaccine in infancy. N Engl J Med 317: 717-722

23. Eskola J, Käyhty H, Takala AK, Peltola H, Rönnberg P-R, Kela E, Pekkanen $E$, McVerry PH, Mäkelä PH (1990) A randomized, prospective field trial of a conjugate vaccine in the protection of infants and young children against invasive Haemophilus influenzae type $\mathrm{b}$ disease. N Engl J Med 323: 1381-1387

24. Farley MM, Stephens DS, Mulks MH (1986) Pathogenesis of IgA1 protease-producing and -nonproducing Haemophilus influenzae in human nasopharyngeal organ cultures. J Infect Dis 154: 752-759
25. Feigin RD (1987) Bacterial meningitis beyond the newborn period. In: Feigin RD, Cherry JD (eds) Textbook of pediatric infectious diseases. Saunders, Philadelphia, pp 439-465

26. Feldman RA, Koehler RE, Fraser DW (1976) Race-specific differences in bacterial meningitis deaths in the United States, 1962-1968. Am J Publ Health 66: 392-396

27. Finland M, Brown JW, Rauh AE (1938) Treatment of pneumococcic meningitis. A study of 10 cases treated with sulfanilamide alone or in various combinations with specific antipneumococci serum and complement, including six recoveries. $\mathrm{N}$ Engl J Med 218: 1033-1044

28. Fishman RA, Sligar K, Hake RB (1977) Effects of leukocytes on brain metabolism in granulocytic brain edema. Ann Neurol 2: 89-94

29. Flexner S (1906) Experimental cerebrospinal meningitis and its serum treatment. JAMA 47: 560-566

30. Flexner S (1913) The result of serum treatment in 1300 cases of epidemic meningitis. J Exp Med 17: 553-576

31. Floyd RF, Federspiel CF, Schaffner W (1974) Bacterial meningitis in urban and rural Tennessee. Am J Epidemiol 99: 395-407

32. Fong IW, Tomkins KB (1984) Penetration of ceftazidime into the cerebrospinal fluid of patients with and without evidence of meningeal inflammation. Antimicrob Agents Chemother 26: 115-116

33. Fortnum HM (1992) Hearing impairment after bacterial meningitis: a review. Arch Dis Child 67: 1128-1133

34. Frasch CE (1989) Vaccines for prevention of meningoccocal disease. Clin Microbiol Rev 2: S134-138

35. Fraser DW, Geil CC, Feldman RA (1974) Bacterial meningitis in Bernalillo County, New Mexico: a comparison with three other American populations. Am J Epidemiol 100: 29-34

36. Garvey RJP, McMullin GP (1983) Meningitis due to $\beta$-lactamase producing type b Haemophilus influenzae resistant to chloramphenicol. BMJ 287: 1183-1184

37. Gigliotti F, Lee D, Insel RA, Scheld WM (1987) IgG penetration into the cerebrospinal fluid in a rabbit model of meningitis. J Infect Dis 156: 394-398

38. Girgis NI, Farid Z, Mikhail IA, Farrag I, Sultan Y, Kilpatrick ME (1989) Dexamethasone treatment for bacterial meningitis in children and adults. Pediatr Infect Dis J 8: 848-851 
39. Glimåker M, Kragsbjerg $P$, Forsgren $M$, Olcén P (1993) Tumor necrosis factor- $\alpha$ (TNF $\alpha)$ in cerebrospinal fluid from patients with meningitis of different etiologies: high levels of TNF $\alpha$ indicate bacterial meningitis. J Infect Dis 167: 882-889

40. Granoff DM, Cates KL (1985) Haemophilus influenzae type b polysaccharide vaccines. J Pediatr 107: 330-336

41. Granoff DM, Anderson EL, Osterholm MT, Holmes SJ, McHugh JE, Belshe RB, Medley F, Murphy TV (1992) Differences in the immunogenicity of three Haemophilus influenzae type $\mathrm{b}$ conjugate vaccines in infants. J Pediatr 121: 187-194

42. Groot de R, Dzoljic-Danilovic G, Klingerden van $\mathrm{B}$, Goessens WHF, Neijens HJ (1991) Antibiotic resistance in Haemophilus influenzae: mechanisms, clinical importance and consequences for therapy. Eur J Pediatr 150: $534-546$

43. Guerra-Romero L, Täuber MG, Fournier MA, Tureen JH (1992) Lactate and glucose concentrations in brain interstitial fluid, cerebrospinal fluid, and serum during experimental pneumococcal meningitis. J Infect Dis 166: 546-550

44. Hatch D, Overturf GD, Kovacs A, Forthal D, Leong C (1986) Treatment of bacterial meningitis with ceftazidime. Pediatr Infect Dis J 5: 416-420

45. Hoffman SL, Rustama D, Punjabi $\mathrm{NH}$, et al (1988) High-dose dexamethasone in quinine-treated patients with cerebral malaria: a double-blind, placebo-controlled trial. J Infect Dis 158: $325-331$

46. Hughes BJ, Hollers JC, CrockettTorabi E, Smith CW (1992) Recruitment of CD $11 \mathrm{~b} / \mathrm{CD} 18$ to the neutrophil surface and adherence-dependent cell locomotion. J Clin Invest 90: 1687-1696

47. Infectious Disease and Immunization Committee, Canadian Paediatric Society (1990) Dexamethasone therapy for bacterial meningitis: a time for caution. Can Med Ássoc J 142: 307-308

48. Ingraham JL, Maaloe $O$, Neidhardt FC (1983) Growth of the bacterial cell. Sinauer Associates 3, Sunderland, MA

49. Kadurugamuwa JL, Hengstler B, Zak $O$ (1987) Effects of antiinflammatory drugs on arachidonic acid metabolites and cerebrospinal fluid proteins during infectious pneumococcal meningitis in rabbits. Pediatr Infect Dis J 6: $1153-1154$

50. Kadurugamuwa JL, Hengstler B, Bray MA, Zak O (1989) Inhibition of complement-factor-5a-induced inflammatory reactions by prostaglandin $E_{2}$ in experimental meningitis. J Infect Dis 160: 715-719
51. Kadurugamuwa JL, Hengstler B, Zak O (1989) Cerebrospinal fluid protein profile in experimental pneumococcal meningitis and its alteration by ampicillin and antiinflammatory agents. J Infect Dis 159: 26-34

52. Kaplan SL, Feigin RD (1978) The syndrome of inappropriate secretion of antidiuretic hormone in children with bacterial meningitis. J Pediatr 92: 758-761

53. Käyhty H, Eskola J, Peltola H, Rönnberg P-R, Kela E, Karanko V, Saarinen L (1991) Antibody responses to four Haemophilus influenzae type b conjugate vaccines. JAMA 145: 223-227

54. Kern JA, Lamb RJ, Reed JC, Daniele RP, Nowell PC (1988) Dexamethasone inhibition of interleukin-1 $\beta$ production by human monocytes. J Clin Invest 81: 237-244

55. King SM, Law B, Langley J, Heurter H, Bremner D, Wang E, Gold R (1992) A randomized controlled trial of dexamethasone versus placebo in children with bacterial meningitis (abstract 72). Program and abstracts of the 32nd Interscience Conference on Antimicrobial Agents and Chemotherapy. Am Soc Microbiol, Washington, p 122

56. Klein NJ, Heyderman RS, Levin M (1992) Antibiotic choices for meningitis beyond the neonatal period. Arch Dis Child 67: 157-161

57. Lebel MH, Freij BJ, Syrogiannopoulos GA, Chrane DF, Jean Hoyt M, Stewart SM, Kennard BD, Olsen KD, McCracken GH (1988) Dexamethason therapy for bacterial meningitis. Result of two double-blind, placebocontrolled trials. N Engl J Med 319: 964-971

58. Lee SW, Tsou AP, Chan H (1988) Glucocorticoids selectively inhibit the transcription of the interleukin- $1 \beta$ gene and decrease the stability of interleukin-1 $\beta$ mRNA. Proc Natl Acad Sci USA 85: 1204-1208

59. Leist TP, Frei K, Kam-Hansen S, Zinkernagel RM, Fontana A (1988) Tumor necrosis factor $\alpha$ in cere brospinal fluid during bacterial, but not viral, meningitis. J Exp Med 167: 1743-1748

60. Ley van der P, Biezen van der J, Hohenstein P, Peeters C, Poolman JT (1993). Use of transformation to construct antigenic hybrids of the class 1 outer membrane protein in Neisseria meningitidis. Infect Immun 61: 42174224

61. López-Cortés LF, Cruz-Ruiz M, Gómez-Mateos J, Jiménez-Hernádez D, Palomino J, Jiménez E (1993) Measurement of levels of tumor necrosis factor- $\alpha$ and interleukin- $1 \beta$ in the CSF of patients with meningitis of different etiologies: utility in the differential diagnosis. Clin Infect Dis $16: 534-539$
62. Lynn WA, Raetz CRH, Qureshi N, Golenbock DT (1991) Lipopolysaccharide-induced stimulation of CD11/CD18 expression on neutrophils. Evidence of specific receptorbased response and inhibition by lipid A-based antagonists. J Immunol 147: 3072-3079

63. Machka K, Braveny I, Dabernat H, Dornbusch K, Dyck E van, Kayser $\mathrm{FH}$, Klingeren B van, Mittermayer $\mathrm{H}$, Perea E, Powell M (1988) Distribution and resistance patterns of Haemophilus influenzae: a European cooperative study. Eur I Clin Microbiol Infect Dis 7: 14-24

64. Marcus AJ (1988) Eicosanoids: transcellular metabolism. In: Gallin JJ, Goldstein IM, Snyderman R (eds) Inflammation: basic principles and clinical correlates. Raven Press, New York, pp 129-138

65. McCracken GH, Mize SG, Threlkeld $\mathrm{N}$ (1980) Intraventricular gentamicin therapy in gram-negative bacillary meningitis of infancy. Report of the second neonatal meningitis cooperative study group. Lancet : 787-791

66. McCracken GH, Mustafa MM, Ramilo O, Olsen KD, Risser RC (1989) Cerebrospinal fluid interleukin 1-beta and tumor necrosis factor concentration and outcome from neonatal gram-negative enteric bacillary meningitis. Pediatr Infect Dis J 8: 155-159

67. Møller B, Mogensen SC, Wendelboe P, Bendtzen K, Petersen CM (1991) Bioactive and inactive forms of tumor necrosis factor- $\alpha$ in spinal fluid from patients with meningitis. $J$ Infect Dis 163: 886-889

68. Moser R, Schleiffenbaum B, Groscurth P, Fehr J (1989) Interleukin 1 and tumor necrosis factor stimulate human vascular endothelial cells to promote transendothelial neutrophil passage. J Clin Invest 83: 444-455

69. Mustafa MM, Lebel MH, Ramilo O, Olsen KD, Reisch JS, Beutler B, McCracken GH (1989) Correlation of interleukin- $1 \beta$ and cachectin concentrations in cerebrospinal fluid and outcome from bacterial meningitis. $\mathrm{J}$ Pediatr 115: 208-213

70. Mustafa MM, Mertsola J, Ramilo O, Sáez-Llorens X, Risser RC, McCracken GH (1989) Increased endotoxin and interleukin- $1 \beta$ concentrations in cerebrospinal fluid of infants with coliform meningitis and ventriculitis associated with intraventricular gentamicin therapy. J Infect Dis 160: 891-895 
71. Mustafa MM, Ramilo O, Mertsola J, Risser RC, Beutler B, Hansen EJ, McCracken GH (1989) Modulation of inflammation and cachectin activity in relation to treatment of experimental Hemophilus influenzae type b meningitis. J Infect Dis 160: 818-825

72. Mustafa MM, Ramilo O, Olsen KD, Franklin PS, Hansen EJ, Beutler B, McCracken GH (1989) Tumor necrosis factor in mediating experimental Haemophilus influezae type b meningitis. J Clin Invest 84: 1253-1259

73. Mustafa MM, Ramilo O, SáezLlorens X, Olsen KD, Magness RR, McCracken GH (1990) Cerebrospinal fluid prostaglandins, interleukin $1 \beta$, and tumor necrosis factor in bacterial meningitis. Clinical and laboratory correlations in placebo-treated and dexamethason-treated patients. Am J Dis Child 144: 883-887

74. Naworth PP, Stern DM (1986) Modulation of endothelial cell hemostatic properties by tumor necrosis factor. J Exp Med 163: 740-745

75. Neu HC (1987) Cephalosporins in the treatment of meningitis. Drugs 34 [Suppl]: 135-153

76. Odio CM, Faingezicht I, Paris M, Nassar M, Baltodano A, Rogers J, Sáez-Llorens X, Olsen KD, McCracken GH (1991) The beneficial effects of early dexamethasone administration in infants and children with bacterial meningitis. N Engl J Med 324: 1525-1531

77. Ohga S, Aoki T, Okada K, Akeda $\mathrm{H}$, Fujioka K, Ohshima A, Mori T, Minamishima, Ueda K (1994) Cerebrospinal fluid concentrations of interleukin- $1 \beta$, tumor necrosis factor- $\alpha$, and interferon gamma in bacterial meningitis. Arch Dis Child 70: 123125

78. Peltola H, Käyhty H, Virtanen M, Mäkelä PH (1984) Prevention of $\mathrm{He}$ mophilus influenzae type $\mathrm{b}$ bacteremic infections with the capsular polysaccharide vaccine. N Engl J Med 310: 1561-1566

79. Peltola H, Kilpi T, Anttila M (1992) Rapid disappearance of Haemophilus influenzae type $\mathrm{b}$ meningitis after routine childhood immunisation with conjugate vaccines. Lancet 340 : 592-594

80. Pfister HW, Koedel U, Haberl RL, Dirnagl U, Feiden W, Ruckdeschel G, Einhäupl KM (1990) Microvascular changes during the early phase of experimental bacterial meningitis. J Cereb Blood Flow Metab 10:914 922
81. Pfister HW, Ködel U, Dirnagl, Haberl RL, Ruckdeschel G, Einhäupl KM (1992) Effect of catalase on regional cerebral blood flow and brain edema during the early phase of experimental pneumococcal meningitis. J Infect Dis 166: 1442-1445

82. Pinckard RN, Ludwig JC, McManus LM (1988) Platelet-activating factors. In: Gallin JJ, Goldstein JM, Snyderman $\mathrm{R}$ (eds) Inflammation: basic principles and clinical correlates. Raven Press, New York, pp 139-168

83. Plaut AG (1983) The IGA1 proteases of pathogenic bacteria. Annu Rev Microbiol 37: 603-622

84. Pober JS, Cotran RS (1990) Cytokines and endothelial cell biology. Physiol Rev 70: 427-451

85. Pober JS, LaPierre LA, Stolpen AH, Brock TA, Springer TA, Fiers W, Bevilacqua MP, Mendrick DL, Gimbrone MA (1987) Activation of cultured endothelial cells by recombinant lymphotoxin: comparison with tumor necrosis factor and interleukin-1 species. J Immunol 138: 3319-3324

86. Pomeroy SL, Holmes SJ, Dodge PR, Feigin RD (1990) Seizures and other neurologic sequelae of bacterial meningitis in children. $\mathrm{N}$ Engl J Med 323: 1651-1657

87. Powell KR, Sugerman LI, Eskenazi AE, Woodlin KA, Kays MA, McCormick KL, Miller ME, Sladek CD (1990) Normalization of plasma arginine vasopressin concentrations when children with meningitis are given maintenance plus replacement fluid therapy. J Pediatr 117: 515-522

88. Prockop L, Fishman R (1966) Pathophysiology of the cerebrospinal fluid changes in experimental pneumococcal meningitis. Trans Am Neurol Assoc 91: 126-131

89. Radetsky M (1990) Duration of treatment in bacterial meningitis: a historical inquiry. Pediatr Infect Dis J 9: 2-9

90. Ramilo O, Mustafa MM, Porter J, Sáez-Llorens X, Mertsola J, Olsen KD, Luby JP, Beutler B, McCracken GH (1990) Detection of interleukin $1 \beta$ but not tumor necrosis factor- $\alpha$ in cerebrospinal fluid in children with aseptic meningitis. Am J Dis Child 144: 349-352

91. Ramilo O, Sáez-Llorens X, Mertsola $J$, et al (1990) Tumor necrosis factor $\alpha /$ cachectin and interleukin-1 $\beta$ initiate meningeal inflammation. J Exp Med 172: 497-507

92. Rodriguez WJ, Puig JR, Khan WN, Feris J, Gold BG, Sturla C (1986) Ceftazidime vs. standard therapy for pediatric meningitis: therapeutic, pharmacologic and epidemiologic observations. Pediatr Infect Dis 5: $408-415$
93. Rothlein R, Czaikowski M, O'Neil MM, Martin D, Mainolfi E, Merluzzi J (1988) Induction of intercellular adhesion molecule- 1 on primary and continuous cell lines by pro-inflammatory cytokines. J Immunol 141: 1665-1669

94. Sáez-Llorens X, Ramilo O, Mustafa MM, Mertsola J, Alba C de, Hansen E, McCracken GH (1990) Pentoxifylline modulates meningeal inflammation in experimental bacterial meningitis. Antimicrob Agents Chemother 34: 837-843

95. Sáez-Llorens X, Jafari HS, Severien C, Parras F, Olsen KD, Hansen EJ, Singer II, McCracken GH (1991) Enhanced attenuation of meningeal inflammation and brain edema by concomitant administration of anti-CD18 monoclonal antibodies and dexamethasone in experimental Haemophilus meningitis. J Clin Invest 88: 2003-2011

96. Sáez-Nieto JA, Lujan R, Berrón, Campos J, Viñas M, Fusté C, Vazquez JA, Zhang QY, Bowler LD, Martinez-Suarez JV, Spratt BG (1992) Epidemiology and molecular basis of penicillin-resistent Neisseria meningitidis in Spain: a 5-year history (1985-1989) Clin Infect Dis 14: 394-402

97. Sapolsky RM, Pulsinelli WA (1985) Glucocorticoids potentiate ischemic injury to neurons: therapeutic implications. Science 1985; 229: 1397-1400

98. Schaad UB, Lips U, Gnehm HE, Blumberg A, Heinzer I, Wedgwood J, for the Swiss Meningitis Study Group (1993) Dexamethasone therapy for bacterial meningitis in children. Lancet 342: 457-461

99. Scheld WM (1987) Morphofunctional alterations of the blood-brain barrier during experimental meningitis. Pediatr Infect Dis J 6: 1145-1146

100. Scheld WM, Dacey RC, Winn HR, Welsh JE, Jane JA, Sande MA (1980) Cerebrospinal fluid outflow resistance in rabbits with experimental meningitis: alterations with penicillin and methylprednisolone. J Clin Invest 66: 243-253

101. Sell SH (1983) Long term sequelae of bacterial meningitis in children. Pediatr Inf Dis 2: 90-93

102. Simasathien S, Duangmani C, Echeverria $P(1980)$ Haemophilus influen$z a e$ type $\mathrm{b}$ resistant to ampicillin and chloramphenicol in an orphanage in Thailand. Lancet II: 1214-1217

103. Springer TA (1990) Adhesion receptors of the immune system. Nature 346: 425-434

104. Steele RW (1989) Cephalosporins for bacterial meningitis: which one is best? J Pediatr 114: 991-992 
105. Steinhoff $\mathrm{MC}$, Edwards $\mathrm{K}$, Keyserling H, Thoms ML, Johnson C, Madore D, Hogerman D (1994) A randomized comparison of three bivalent Streptococcus pneumoniae glycoprotein conjugate vaccines in young children: effect of polysaccharide size and linkage characteristics. Pediatr Infect Dis I 13: 368-372

106. Stephens DS, Farley MM (1991) Pathogenic events during infection of the human nasopharynx with Neisseria meningitidis and Haemophilus influenzae. Rev Infect Dis 13: 22-33

107. Stephens DS, Hoffman LH, McGee ZA (1983) Interaction of Neisseria meningitidis with human nasopharyngeal mucosa: attachment and entry into columnar epithelial cells. J Infect Dis 148: $369-376$

108. Sullivan GW, Carper HT, Novick WJ, Mandell GL (1988) Inhibition of inflammatory action of interleukin-1 and tumor necrosis factor (alpha) on. neutrophil function by pentoxifylline. Infect Immun 57: 1722-1729

109. Syrogiannopoulos GA, Olsen KD, Reisch JS, McCracken GH (1987) Dexamethasone in the treatment of experimental Haemophilus influenzae type b meningitis. J Infect Dis 155 : 213-219

110. Syrogiannopoulos GA, Hansen EJ, Erwin AL, Munford RS, Rutledge J, Reisch JS, McCracken GH (1988) Haemophilus influenzae type b lipooligosaccharide induces meningeal inflammation. J Infect Dis 157: 237 244

111. Täuber MG, Khayam-Bashi H, Sande MA (1985) Effects of ampicillin and corticosteroids on brain water content, cerebrospinal fluid pressure, and cerebrospinal fluid lactate levels in experimental pneumococcal meningitis. Infect Dis 151: 528-534

112. Täuber MG, Shibl AM, Hackbarth CJ, Larrick JW, Sande MA (1987) Antibiotic therapy, endotoxin concentration in cerebrospinal fluid, and brain edema in experimental $E s$ cherichia coli meningitis in rabbits. $\mathbf{J}$ Infect Dis 156: 528-534

113. Täuber MG, Borschberg U, Sande SA (1988) Influence of granulocytes on brain edema, intracranial pressure, and cerebrospinal fluid concentrations of lactate and protein in experimental meningitis. J Infect Dis 157: 456-464

114. Täuber MG, Sande E, Fournier MA, Tureen JH, Sande MA (1993) Fluid administration, brain edema, and cerebrospinal fluid lactate and glucose concentrations in experimental $E s$ cherichia coli meningitis. J Infect Dis 168: $473-476$
115. Taylor HG, Michaels RH, Mazur PM, Bauer RE, Liden CB (1984) Intellectual, neuropsychological, and achievement outcomes in children six to eight years after recovery from Haemophilus influenzae meningitis. Pediatrics 74: 198-205

116. Taylor HG, Mills EL, Ciampi A, Berger $R$ du, Watters GV, Gold R, MacDonald N, Michaels RH (1990) The sequelae of Haemophilus influenzae meningitis in school-age children. N Engl J Med 323: 1657-1663

117. Tuomanen E, Tomasz A, Hengstler B, Zak O (1985) The relative role of bacterial cell wall and capsule in the induction of inflammation in pneumococcal meningitis. J Infect Dis 151: 535-540

118. Tuomanen E, Liu H, Hengstler B, Zak O, Tomasz A (1985) The induction of meningeal inflammation by components of the pneumococcal cell wall. J Infect Dis 151: 858-868

119. Tuomanen E, Hengstler B, Rich R, Bray MA, Zak O, Tomasz A (1987) Nonsteroidal anti-inflammatory agents in the therapy for experimental pneumococcal meningitis. J Infect Dis 155: 985-990

120. Tuomanen EI, Saukkonen K, Sande S, Cioffe C, Wright SD (1989) Reduction of inflammation, tissue damage, and mortality in bacterial meningitis in rabbits treated with monoclonal antibodies against adhesionpromoting receptors of leukocytes. $\mathbf{J}$ Exp Med 170: 959-968

121. Tureen JH, Stella FB, Clyman RI, Mauray F, Sande MA (1987) Effect of indomethacin on brain water content, cerebrospinal fluid white blood cell response and prostaglandin $\mathrm{E}_{2}$ levels in experimental pneumococcal meningitis in rabbits. Pediatr Infect Dis J 6: 1151-1153

122. Tureen JH, Täuber MG, Sande MA (1991) Effect of indomethacin on the pathophysiology of experimental meningitis in rabbits. J Infect Dis 163 : 647-649

123. Tureen JH, Täuber MG, Sande MA (1992) Effect of hydration status on cerebral blood flow and cerebrospinal fluid lactic acidosis in rabbits with experimental meningitis. J Clin Invest 89: 947-953

124. Uchiyama N, Greene GR, Kitts DB, Thrupp LD (1980) Meningitis due to Haemophilus influenzae type b resistant to ampicillin and chloramphenicol. J Pediatr 97: 421-424

125. Valone FH, Epstein LB (1988) Biphasic platelet-activating factor synthesis by human monocytes stimulated with IL-1 $\beta$, tumor necrosis factor, or IFNgamma. J Immunol 141: 3945-3950
126. Waage A, Halstensen A, Shalaby R, Brandtzaeg P, Kierulf P, Espevik T (1989) Local production of tumor necrosis factor $\alpha$, interleukin 1 , and interleukin 6 in meningococcal meningitis. J Exp Med 170: 1859 1867

127. WaId E, US Meningitis Study Group (1992) Dexamethasone for children with bacterial meningitis (abstract 73). Program and abstracts of the 32nd Interscience Conference on Antimicrobial Agents and Chemotherapy. Am Soc Microbiol, Washington, pp 123

128. Walterspiel JW, Kaplan SL, Mason EO (1986) Protective effect of subinhibitory polymyxin $\mathrm{B}$ alone and in combination with ampicillin for overwhelming Haemophilus influenzae type $b$ infection in the infant rat: evidence for in vivo and in vitro release of free endotoxin after ampicillin treatment. Pediatr Res 20: 237-241

129. Watemberg N, Dagan R, Arbelli Y, Belmaker I, Morag A, Hessel L, Fritzell B, Bajard A, Peyron L (1991) Safety and immunogenicity of Haemophilus influenzae type b-tetanus protein conjugate vaccine, mixed in the same syringe with diphtheria-tetanuspertussis vaccine in young infants. Pediatr Infect Dis J 10: 758-761

130. Wenger JD, Hightower AW, Facklam RR, Gaventa S, Broome CV, and the Bacterial Meningitis Study group (1990) Bacterial meningitis in the United States, 1986: report of a multistate surveillance study. J Infect Dis 162: 1316-1323

131. Wispelwey B, Lesse AJ, Hansen EJ, Scheld WM (1988) Haemophilus influenzae lipopolysaccharide-induced blood brain barrier permeability during experimental meningitis in the rat. $\mathrm{J}$ Clin Invest 82: 1339-1346

132. Wotton KA, Stiver HG, Hildes JA (1981) Meningitis in the central Arctic: a 4-year experience. Can Med Assoc J 124: 887-890

133. Ziegler EJ, McCutchan JA, Fierer J, Glauser MP, Sadoff JC, Douglas H, Braude AI (1982) Treatment of gramnegative bacteremia and shock with human antiserum to a mutant $E s$ cherichia coli. N Engl J Med 307 : 1225-1230

134. Ziegler EJ, Fisher CJ, Sprung CL, Straube RC, Sadoff JC, Foulke GE, Wortel CH, Fink MP, Dellinger RP, Teng NNH, Allen IE, Berger HJ, Knatterud GL, LoBuglio AF, Smith CR, HA-1A Sepsis Study Group (1991) Treatment of gram-negative bacteremia and septic shock with HA1A human monoclonal antibody against endotoxin. N Engl J Med 324: 429- 436 